UDC 330

DOI: $10.31891 / 2307-5740-2021-298-5(1)-19$

LILIYA KHOMENKO

ORCID: 0000-0001-5690-1105 e-mail: 1.khomenko@fem.sumdu.edu.ua

LYDMILA SAHER

ORCID: 0000-0002-5628-5477

e-mail: lyudmila.sager@gmail.com Sumy State University

\title{
SEMIOTIC ANALYSIS OF LOGOS AS A MARKETING PROMOTION TOOL FOR BLOOD SERVICE ENTERPRISES
}

The article conducted a comparative analysis of the blood services' logos, identified the features of their constituent elements for the new logo's development or existing logo's rebranding, and suggested ways to increase their efficiency. It was found 100 logos of various blood service establishments on the Internet, in particular on the official websites of the establishments and official pages on social networks, 43 of them - Europe (12 of them - Ukraine), 13 - Asia, 19 - South and North America, 15 - Africa, 10 - Australia and Oceania. There were explored the following aspects: symbolic and font elements in the logo, the colors used and their quantity, the main messages of identity, and regional differences. There were used general scientific analytical methods and analogies and prototypes to obtain practical results during the study.

This study indicates that most blood establishments in the region are characterized by combined compositions in logos - a combination of the font with a visual component but with a fairly direct connotation. The most popular colors in the blood service are red, blue, black, and white font. Logos most often use 2 colors (except white), less often 1 or 3 . The following blood service symbols are most often used: a drop of blood, heart, cross, person, and hands. There is also a circle, a crescent moon, a pelican, a star, and a butterfly. They stimulate a certain type of behavior and affect feelings. The results of this research allow to create a good separation from competitors and several times increase the marketing performance of the newly formed organization or existing. Blood service institutions can use this study's results to rebrand the organization and organizations' owners to develop the future brand's identity.

Keywords: logo, branding, blood service, corporate identity, semiotics, marketing promotion

ХОМЕНКО ЛІЛІЯ, САГЕР ЛЮДМИЛА

Сумський державний університет

\section{СЕМІОТИЧНИЙ АНАЛІЗ ЛОГОТИПІВ ЯК ІНСТРУМЕНТ МАРКЕТИНГОВОГО ПРОСУВАННЯ ПІДПРИЕМСТВ СЛУЖБИ КРОВІ}

У статті проведено порівняльний аналіз логотипів закладів служби крові, виявлено особливості їх складових елементів для подальшої розробки нового логотипу або для ребредингу існуючого та запропоновано шляхи підвищення його ефективності. Було знайдено 100 логотипів різних закладів служби крові в мережі Інтернет, зокрема на офіційних сайтах закладів та офіційних сторінках в соціальних мережах, з них 43 - Європа (з них 12 - Україна), 13 - Азія, 19 - Південна та Північна Америка, 15 - Африка, 10 - Австралія та Океанія. Було досліджено наступні аспекти: використання символьних та шрифтових елементів в логотипі, кольори, що використовуються та їх кількість, головні посили айдентики та регіональні відмінності. Під час проведення дослідження використовувались загальнонаукові аналітичні методи, а також методи аналогії та прототипів для отримання практичних результатів.

Результати даного дослідження свідчать про те, що для більшості закладів служби крові регіону характерні комбіновані композиції в логотипах - це поєднання шрифту з візуальною складовою, але з досить прямим підтекстом. Найпопулярніші кольори в службі крові - червоний і синій разом з чорно-білим шрифтом. у логотипах найчастіше використовується 2 кольори (крім білого), рідше 1 або 3. Найчастіше використовуються такі символи служби крові: крапля крові, серце, хрест, людина і руки. Також зустрічаються коло, півмісяць, пелікан, зірка і метелик. Вони стимулюють певний тип поведінки та впливають на почуття. Результати даного дослідження дозволяють створити гарне відокремлення від конкурентів і в кілька разів підвищити маркетингові показники нової створеної або існуючої організації. Результати даного дослідження можуть бути використані установами служби крові при ребрендингу організації, а також власниками організацій для розробки айдентики майбутнього бренду.

Ключові слова: логотип, брендинг, служба крові, фірмовий стиль, семіотика, маркетингове просування

Problem statement in general and its connection with important scientific or practical tasks

A logo is an important component of any company's image. Without a logo, it is difficult to identify a company to a consumer. It is impossible to form and promote the brand, to form or change consumer preferences without a logo.

A logo is an important visual communication tool, especially for promotional activity, brand identity, and campaigns. It is also a necessary means to disseminate public information.

The logo is important in creating the company's advertising concept and further promoting it in the market. The logo allows identifying the company from hundreds of others in the consumer's eyes. It sets the direction in the further branding and marketing system for the company. and clearly.

The logo allows customers to visualize the image. It helps to show the company's products or services shorty 
The logo's importance is growing every day because this element will be on all, without exception, the company's advertising media: video advertising, printing booklets, postcards, business cards, souvenirs, gifts to customers more others. And so, should give the creation of the logo maximum attention.

Logo - a graphic image of the brand created to recognize the company's brand among consumers easily. It was designed to distinguish the products of manufacturers from one industry.

Many companies offer almost the same services or products, becoming increasingly difficult to stand out among them. A logo is one of the tools that allows you to identify a company and distinguish one company from another. The company uses the logo on all advertising materials, events, communication channels. He was one of the first to develop the company's corporate identity.

However, the logo's illustration has certain specific requirements: the small space available for the image. Some companies post only a graphic image, others the organization's name, others both the name and the graphic image.

Logos differ in type (symbolic, letter, emblem, abstract signs, etc.), in the use of colors and their combinations, in form, in meaning. Thanks to these characteristics, it helps to stand out from other competitors.

One of the first logos, among the world-famous brands, is the American (international) company Prudential Insurance, which deals with finance and real estate. The logo depicts the rocks of Gibraltar. It is still used by the company [1].

Since then, most countries on all continents have created their own logos, blood service facilities, and organizations working in this field too.

\section{Analysis of recent research and publications}

The number of publications on the blood service's marketing activities is increasing every year, but logos in the blood service has hardly been studied. Research has been found on the use of logos and their features in various sectors of the economy. The influence of brand colors to influence the target audience was studied [2], the essence of logos and their classification [3], logo design and its features [4], semi-automatic color analysis for brand logos [5].

Semiotic analysis is most often used to analyze logos and other visual marketing tools. Thus, with the help of semiotic analysis, there were studied the logos of Ethiopian state universities [6], the logo of the "Made in India" campaign [7], the logos of medical centers in Belarus, Russia, and abroad [8], the logos of restaurants and confectionery in Belarus, Russia and abroad [9].

\section{Selection of previously unresolved parts of the problem}

No work has been found on the use of logos in the blood service. There are studies on blood service as the semiotic analysis of postage stamps in the blood service [10] and posters [11]. Also, there were analyzed marketing activities in blood service with other methods [12-15]. So this issue needs further study on using logos in the blood service in Ukraine.

\section{Formulation of the goals of the article}

The article's main purpose is to conduct a consistent comparative analysis of the logos of blood establishments and organizations working in this field and identify their constituent elements features to develop the logo of a new establishment of rebranding.

Therefore, the objectives of the study are as follows:

- explore the use of graphic and font elements in the logo,

- explore the color palette used in the logos of blood service facilities,

- determine the number of colors used in the logos,

- identify the main messages of identity and their meaning,

- analyze the differences in existing logos by region.

To highlight repetitive or specific characteristics, we have collected and studied a significant part of the logos used by various institutions of the world's blood service and organizations working in this field.

For each logo, we obtained a photo of its image reproduction. We noted the different characteristics: country, image, text, or a combination thereof, the dominant colors and themes of the illustrations. This article presents this study's results, which define blood service's general idea in different countries' logos.

\section{Methodology and research methods}

It is hypothesized that there are general trends in logos of companies operating in the same industry. Still, there are some differences related to the characteristics of consumers by regional affiliation. Therefore, the study compares companies' logos operating in Ukraine with companies' logos in different world regions.

This work begins with a review of the work on analyzing logos and identifying those gaps that provide new opportunities.

The logos of various blood service establishments were searched on the Internet, particularly on the establishments' official websites and on the official pages of social networks. There were found 100 logos of blood service establishments. 43 logos found in Europe (12 of them in Ukraine), 13 in Asia, 19 in South and North America, 15 in Africa, 10 in Australia and Oceania.

The comparison of logos was based on analyzing the logos of Ukraine and other countries' blood service establishments.

It was used the semiotic analysis method, in which were analyzed verbal and visual signals symbolic messages. 
There were investigated the following aspects: the use of symbolic and font elements in the logo, the colors used and their number, the main messages of identity (message symbols).

General scientific analytical methods, analogy, and prototype methods were used to obtain practical results during the study. There were found 100 logos from 58 countries of blood service institutions and organizations working in this field.

All logos by the system of countries were systematized. There were studied colors and their number in the logo, logo's types, and the main messages of the identity.

Presentation of the main research material

Figures 1-6 show the logos of blood establishments and related organizations by region: Ukraine (Fig. 1), Europe (Fig. 2), Asia (Fig. 3), North and South America (Fig. 4), Africa (Fig. 5), Australia and Oceania (Fig. 6).

There were found 12 logos in Ukraine (fig. 1). These are logos of 11 regional blood services centers: Sumy, Chernihiv, Ivano-Frankivsk, Ternopil, Kherson, Kyiv, Kharkiv, Vinnytsia, Zaporizhzhia, Zhytomyr Blood Service Centers, and Kyiv City Blood Service Center.

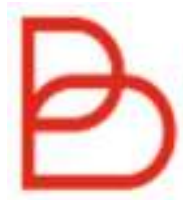
Cymen

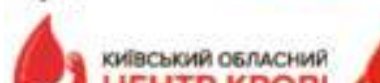

ЦLEHTP КРОВI

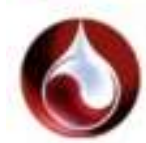

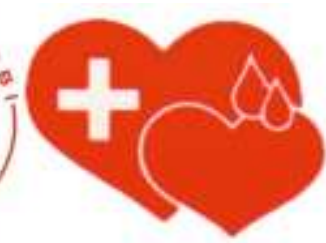

\section{( СЛУЖКБК КРОВІ: \\ киЇвСький миськй IUEHTP КРOBI}

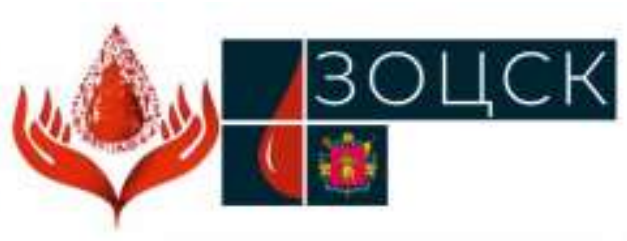

Fig. 1. Logos of blood services in Ukraine (Sumy, Chernihiv, Kherson, Rivne, Vinnytsia, Zaporizhzhia, Kyiv region, Kharkiv, IvanoFrankivsk, Ternopil, Kyiv city, Zhytomyr)

$58.3 \%$ of them are combined, have both letters and graphic symbolic, $33.3 \%$ contain only graphic symbolic, and one $(8.4 \%)$ use the abbreviation. They mainly have red colors $(91.7 \%)$ with combines of white or yellow. Usually $(66.7 \%)$, they have 1 or 2 colors. The most common symbols are a drop (83.3\%) and a heart $(33.3 \%)$. Less often are used men (25\%), circle (25\%), hands (16.7\%), and cross $(16.7 \%)$. Most of them contain a few elements.

In Europe, there were found 31 logos: 5 - European part of Russia, 4 - United Kindom, 2 - Iceland, by 1 Andorra, Belgium, Belorussia, Cyprus, Estonia, Finland, France, Greece, Ireland, Italy, Latvia, Lithuania, Malta, Netherland, Norway, Portugal, Serbia, Slovenia, Sweden, Switzerland (fig. 2).

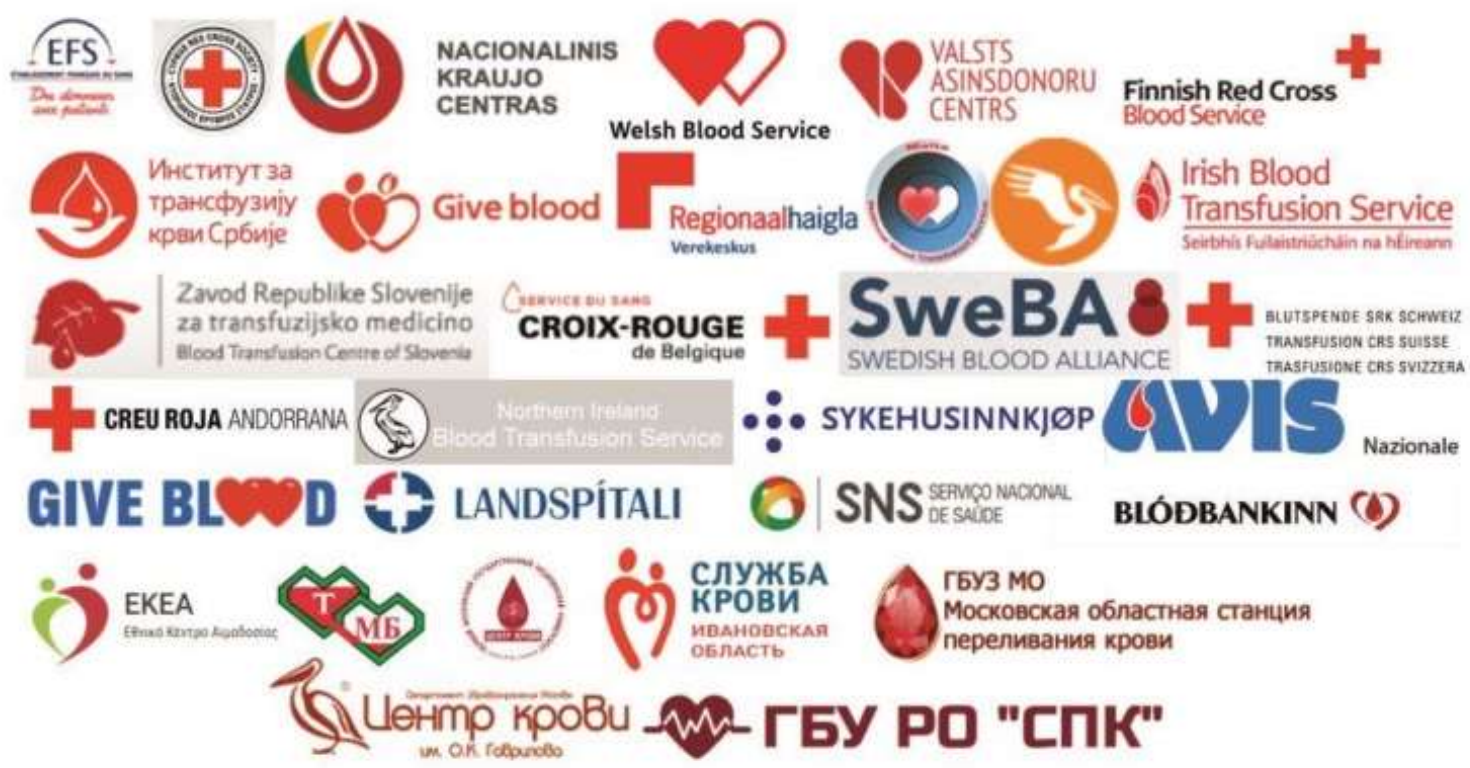

Fig. 2. Logos of blood services from Europe (France, Cyprus, Lithuania, Great Britain, Latvia, Finland, Serbia, Great Brita in, Estonia, Malta, Netherland, Ireland, Slovenia, Belgium, Sweden, Switzerland, Andorra, Great Britain, Norway, Italy, Great Britain, Ice land, Portugal, Iceland, Greece, Belorussia, Russia - 5 logos) 
Almost all of them $(96.7 \%)$ are combined, have both letters and graphic symbolic, $3.2 \%$ contain only graphic symbolically, and 2 (6.4\%) use the abbreviation. The main colors used in logos are red (67.7\%), blue (29.0\%), and black (25.8). Also, there are used green (12.9\%), yellow (6.5\%), and orange (3.2\%). They use one (25.8\%), two $(51.6 \%)$, three $(9.8 \%)$ or four $(6.5 \%)$ colors. The most common symbols are a circle $(32.2 \%)$, drop $(29.0 \%)$, heart (25.8\%). Also are used cross (6.5\%), men (6.5\%) and hands (1). In European logos, symbols were used, which weren't in Ukrainian logos as the pelican (9.7\%), leaves (3.2\%). The Netherlands blood service logo is very different from others. It has a pelican on the orange background. Norway's and Sweden's blood services logos also differ from the others because they do not contain a direct reference to the symbols of the blood service (drop, heart, pelican, cross). Only a concise name and circles.

In Asia, there were found 13 logos: 4 in Russia, by 1 in Bangladesh, Cambodia, Georgia, Iraq, Israel, Japan, Kazakhstan, Philippines, Singapore (fig. 3).

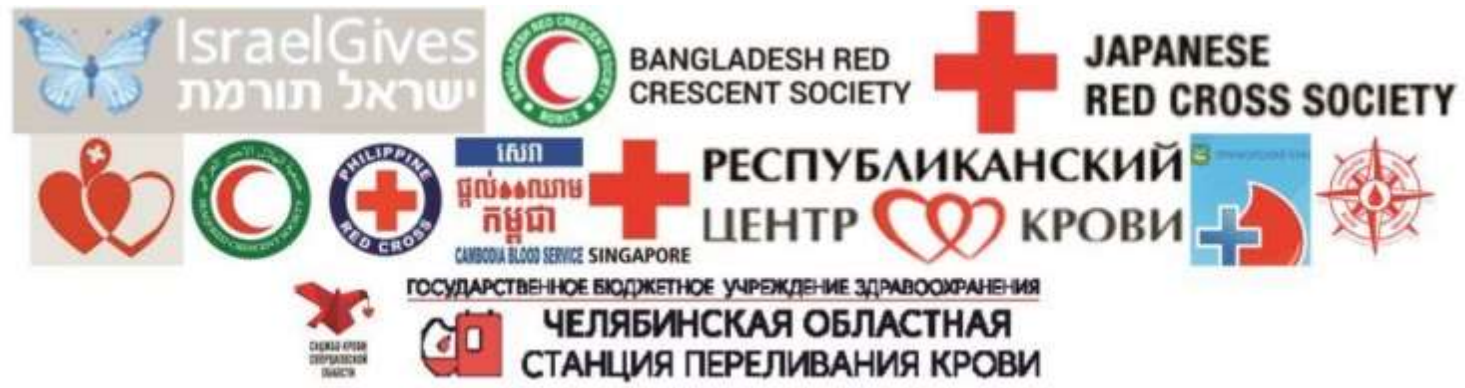

Fig. 3. Logos of blood services from Asia (Israel, Bangladesh, Japan, Georgia, Iraq, Philippine, Cambodia, Singapore, Russia - 5 logos)

Almost all of them (92.3\%) are combined, have both letters and graphic symbolic, $7.7 \%$ contain only graphic symbolism, and no one uses the abbreviation. The main colors used in logos are red $(92.3 \%)$, blue $(30.7 \%)$, and black (38.4). Also, there are used green $(15.4 \%)$, which is not in Ukrainian logos. The most common symbols are cross $(30.7 \%)$, a circle $(30.7 \%)$, drop $(15.4 \%)$, heart (15.4\%). In no one, logos are used the men and hands. But they contain symbols, which weren't in Ukrainian logos as a crescent (15.4\%), butterfly (7.7\%), and blood container (7.7\%). The Israel blood service logo with a butterfly is very different from others.

In North and South America, there were found 19 logos: 13 in the USA, two in Trinidad and Tobago, by one in Antigua and Barbuda, Belize, Canada, Jamaica (fig. 4).

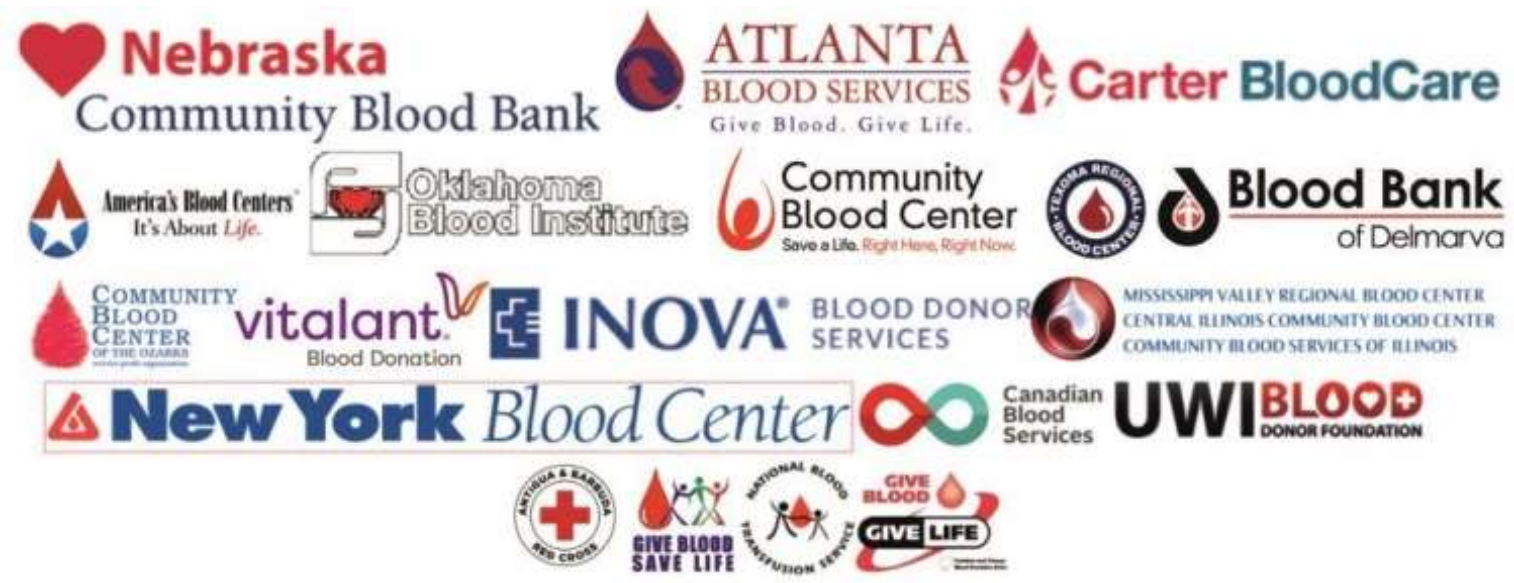

Fig. 4. Logos of blood services from North and South America (USA - 13 logo, Canada, Trinidad and Tobago, Antigua and Barbuda, Belize, Jamaica, Trinidad and Tobago, USA)

All of them are combined, have both letters and graphic symbolic, and no one uses only letters or the abbreviation. They mainly have red (94.7) or blue colors (52.6\%) with combines of white or black (47.4\%). Two logos $(10.5 \%)$ use violet colors. Usually $(66.7 \%)$ they have $2(47.4 \%)$ or more $(26.3 \%)$ colors, only one logo has 1 color $(5.3 \%)$. The most common symbols are a drop (10\%) and men (5\%). Less often are used as a circle (4\%), heart (3\%), and cross (3\%). Also, there are used arrows, infinity, triangle, star, and butterfly (by 5.3\%), not in the Ukrainian logos. One USA logo (Vitalant) with violet color and butterfly is very different from others.

In Africa, There were found 12 logos: 2 in Mauritania, 2 in Namibia, 2 in Egypt, by one in Algeria, Benin, Botswana, Cameroon, Ghana, Kenya, Nigeria, South Africa, Zimbabwe (fig. 5). 


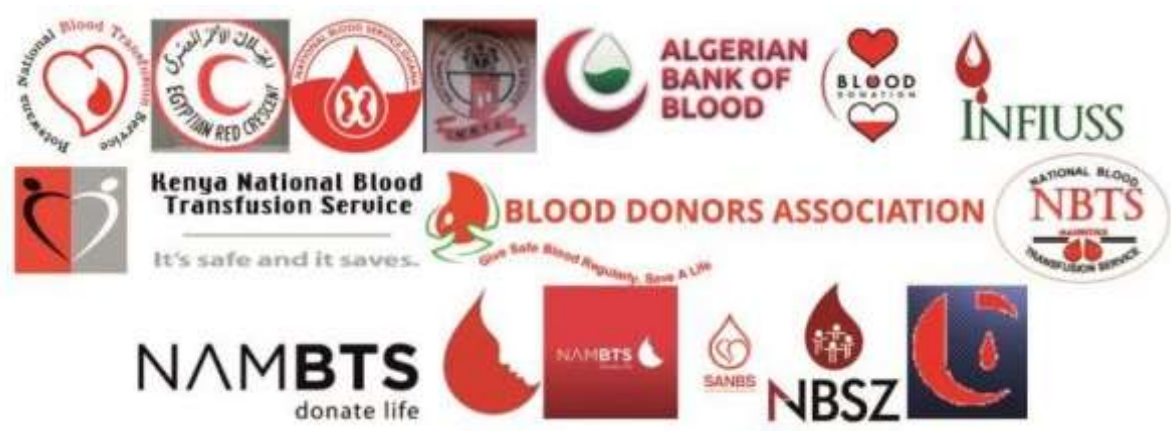

Fig. 5. Logos of blood services from Africa (Botswana, Egypt, Ghana, Benin, Algerian, Nigeria, Cameroon, Kenya, Mauritius - 2 logos, Namibia - 2 logos, South Africa, Zimbabwe, Egypt)

Most of them (93.3\%) are combined, have both letters and graphic symbolic, $6.6 \%$ contain only graphic symbolic, and one $(33.3 \%)$ use the abbreviation. They all have red colors with combines of white or black. Three $\operatorname{logos}(20 \%)$ have a green color, and one $(7.3 \%)$ - blue. Usually, 2 colors $(86.7 \%)$. By one, logos have one or three colors $(6.7 \%)$. The most common symbols are a drop (46.7\%), circle (33.3\%), less often are used a heart $(13.3 \%)$, men $(6.7 \%)$, hands $(6.7 \%)$, and no one has the cross. Some logos show crescent $(20 \%)$. They all are very similar to each other.

In Australia and Oceania, there were found 10 logos: two in Palau, by one in Australia, Fiji, Caribbean, Marshall Islands, New Zealand, Papua New Guinea, Solomon Islands (fig. 6).

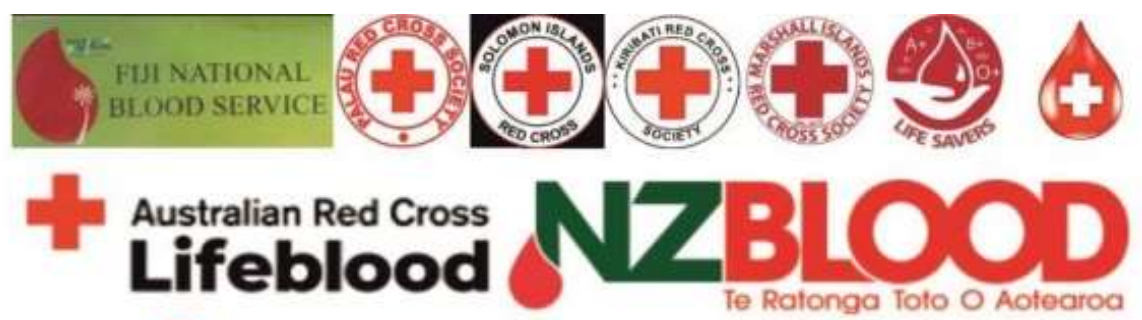

\section{PALAU RED CROSS SOCIETY}

Fig. 6. Logos of blood services from Australia and Oceania (Fiji, Palau, Solomon Islands, Kiribati, Marshall Islands - 2 logos, Papua New Guinea, Australia, New Zealand, Palau)

Most of them are the logos of the Red Cross, which deals with blood donation. Not all countries have their own blood service logos. The most common color is red (with white or black) in logos, seldom - green $(20 \%)$. The most common symbols are cross $(70 \%)$, a drop (30\%), and hand $(10 \%)$.

The question arises which elements (symbolic or font) are most often used in logos, which colors and their number, and which ideas are embedded in the logo.

Character and font elements. Use of symbolic and font elements in the logo. An analysis of 100 logos revealed that the most commonly used letter and graphic symbol elements are found in most logos (90\%), most combined type logos combine different elements (86\%). Almost a third of logos are emblems, with less common abbreviations \%). Most emblems are used in Australia and Oceania (78\%). Abbreviations are most common in Africa $(33 \%)$ and Europe (17\%).

Table 1

Character and font elements in logos (developed by the authors)

\begin{tabular}{|l|c|c|c|c|c|c|c|}
\hline \multicolumn{1}{|c|}{ Elements in the logo } & Ukraine & Europe & Asia & America & Africa & Australia & Together \\
\hline Letters & 8 & 29 & 11 & 19 & 14 & 9 \\
\hline Abbreviations & 1 & 5 & 0 & 1 & 5 & 1 \\
\hline Graphic symbolic & 9 & 27 & 12 & 18 & 15 & 10 \\
\hline Emblems & 3 & 6 & 4 & 3 & 5 & 10 & 7 \\
\hline Combined & 9 & 25 & 11 & 18 & 14 & 91 \\
\hline
\end{tabular}

Color palette. The logos of blood establishments most often use 3 colors (in descending order): red in combination with white ( $95 \%$ of logos), black ( $36 \%$ of logos), and blue ( $24 \%$ of logos). There are also green, gray, yellow, purple, and orange. Red is found in the following symbols:

- a drop of blood;

- a container of blood;

- a red cross;

- a red crescent; 
- a symbol of the heart or blood circulation in the vascular system.

In psychology, red is the joy of life, optimism, cheerfulness; it universally symbolizes life, warmth, and regeneration. Green is the color of spring regeneration and hope. Black and white are used for contrast, mainly in fonts.

Colors in logos (except white) (developed by the author)

\begin{tabular}{l|l|l|l}
\hline Region & Colors used in the logo \\
\hline Ukraine & & & \\
\hline Europe & & & \\
\hline Asia & & & \\
\hline America & & \\
\hline Africa & & \\
\hline Australia and & & \\
\hline Oceania
\end{tabular}

Table 2

Most varieties of colors in logos are used in European countries. Blue is the most popular color in America. It symbolizes spirituality, rest; it is also the color of tolerance. Purple was also was found in American logos, which was not the case in other regions; it symbolizes involvement in something unknown. There are only three colors in Africa, Australia and Oceania: red, black, and green. Colors that have never been encountered were also highlighted: pink and brown. The number of colors. Logos usually use 2 colors $(61 \%)$ or only one ( $23 \%$, often red). Less common are 3 colors (13\%). The maximum number of colors is $4(3 \%)$.

Number of colors in logos (except white) (developed by the author)

\begin{tabular}{|c|c|c|c|c|c|c|c|}
\hline Number of colors in logos & Ukraine & Europe & Asia & America & Africa & Australia & Together \\
\hline One & 5 & 9 & 2 & 1 & 3 & 3 & 23 \\
\hline Two & 5 & 17 & 9 & 13 & 11 & 6 & 61 \\
\hline Three & 1 & 3 & 2 & 5 & 1 & 1 & 13 \\
\hline Four and more & 1 & 2 & 0 & 0 & 0 & 0 & 3 \\
\hline
\end{tabular}

In Ukraine, 1 or 2 colors are most often used (42\% each). In American countries, logos with 3 colors are quite common (26\%). Four or more colors are found only in European blood service' logos institutions (including Ukraine).

The main message of identity. Among the selected images are observed in descending order a drop of blood (39 logos), heart (29 logos), cross (22 logos), men (14 logos), hands (6 logos), circle (5 logos), crescent (5 logos), pelican (3 logos), stars ( 2 logos) and butterfly ( 2 logos). Quite often, 2-3 symbols are combined in one logo (drop and heart, men and drop, etc.).

Some symbols are directly related to blood donation (a drop of blood, outstretched arms, a container of blood), while others are international symbols (red cross, red crescent). The heart does not belong to these groups, but it symbolizes generosity and altruism: who gives from the heart.

Table 4

Symbols of logos in the service of blood (developed by the author)

\begin{tabular}{|c|c|c|c|c|c|c|c|}
\hline The symbol & Ukraine & Europe & Asia & America & Africa & Australia & Together \\
\hline A drop of blood & 9 & 10 & 3 & 7 & 7 & 3 & 39 \\
\hline Heart & 4 & 8 & 4 & 8 & 5 & - & 29 \\
\hline Cross & 2 & 6 & 4 & 3 & - & 7 & 22 \\
\hline Men & 3 & 2 & - & 4 & 5 & - & 14 \\
\hline Hands & 2 & 1 & - & 1 & 1 & 1 & 6 \\
\hline Circle & - & 5 & - & - & - & - & 5 \\
\hline Crescent & - & - & 2 & - & 3 & - & 5 \\
\hline Pelican & - & 3 & - & - & - & - & 3 \\
\hline Star & - & - & 1 & 1 & - & - & 2 \\
\hline Butterfly & - & - & 1 & 1 & - & - & 2 \\
\hline Other & - & 1 & 1 & 2 & & 1 & 5 \\
\hline
\end{tabular}

A drop of blood is most represented in Ukraine (75\% of logos) and Africa (47\%), least in Asia (23\%). The heart is most common in American countries (42\%) and is completely absent from Australia and Oceania's logos. $70 \%$ of Australia and Oceania's logos (Kiribati, Marshall Islands, Palau, Papua New Guinea, Solomon Islands) depict a cross and are completely absent in African countries. Men's image is most common in American countries (Jamaica, Baileys, and the United States) and absent in Asia and Australia. 
Outstretched hands, begging, or giving as a symbol of physical and spiritual energy transfer are used in 6 logos of blood service institutions (everywhere). The circle (5 logos of European countries) and the sign of infinity (Canada) symbolize continuity and unity. The crescent sign (Bangladesh, Iraq, Algeria, and Egypt) is most likely related to religious preferences.

There is an image of a pelican in the logos of blood establishments in some European countries (Netherlands, Russia, Northern Ireland) to symbolize selfless parental love. According to legend, the pelican tore its own breast with its beak and fed the hungry chicks with its blood to save them from death.

The flower on the logo (Fiji) and the leaf with the drop (Slovenia) symbolize health and enrichment or filling (as water enriches plants).

The star as a symbol of human free will is found in Russia and the United States' logos. The butterfly as a symbol of the soul, rebirth, and resurrection is also found in Israel and the United States' logos.

Conclusions from this study and prospects for further exploration in this direction

Most blood establishments in the region are characterized by combined compositions in logos - a font with a visual component but with a fairly direct connotation.

The most popular colors in the blood service are red and blue paired with black and white font.

Logos most often use 2 colors (except white), less often 1 or 3.

The most commonly used symbols of the blood service are a drop of blood, heart, cross, man, and hands. There is also a circle, a crescent moon, a pelican, a star, and a butterfly. They stimulate a certain type of behavior and affect feelings.

This study of logos confirms that by assembling such a powerful comparative base of components, colors, and their combinations, symbols, and messages, you can create a good separation from competitors and several times increase the marketing performance of the newly created organization or existing.

Blood service institutions can use this study's results in the organization's rebranding and the organizations' owners to develop the future brand's identity.

\section{References}

1. Prosvyryna A. Istoriia lohotypu [History of the logo] / A. Prosvyryna // Koloro. - 23.06.2011. - URL : https://koloro.ua/ua/blog/dizain/istoriya-logotipa.html. (Accesses: 28.02.2021).

2. Makhnusha S.M. Analiz brend-kolorystyky yak instrumentu vplyvu na tsilovu audytoriiu Brenda [Analysis of brand color as an instrument of influence on the brand audience] / S.M. Makhnusha, N.Ye. Kosolap // Marketynh i menedzhment innovatsii [Marketing and management innovation]. - 2011. - 2. - P. 95-104.

3. Lazarchuk A. Vyznachennia sutnosti lohotypiv ta yikh klasyfikatsiia [Defining the essence of logos and their classification] / A. Lazarchuk. - 2014. - URL : https://naub.oa.edu.ua/2014/vyznachennya-sutnosti-lohotypiv-ta-jih-klasyfikatsiya/ (Accesses: 28.02.2021).

4. Kuprina Yu. P. Dyzain lohotypa y eho osobennosty [Logo design and its features] / Yu. P. Kuprina. - Sotsialno-ekonomicheskie yavleniya $i$ protsessyi [Socio-economic phenomena and processes]. $\quad$ - 2014. - 3(061). - P. 243-248. - URL https://cyberleninka.ru/article/n/dizayn-logotipa-i-ego-osobennosti/viewer (Accesses: 28.02.2021).

5. Bartneck Ch. Semi-automatic color analysis for brand logos / Ch. Bartneck, A. Clark // Color Research And Application. - 2015. 1(40). - P. 72-84.

6. Mohammed J. The Theory of Ethiopian Logos: A Semiotics Analysis / J. Mohammed // Jurnal Komunikasi-Malaysian Journal Of Communication. - 2020. - 1(36). - P. 41-60.

7. Joshi A. Logo dynamics for investment branding: a visual-semiotic analysis of the reframing devices in the Make in India logo / A. Joshi // Place Branding And Public Diplomacy. - 2018. - 3(14). - P. 163-174.

8. Mnogo sinego, serdtse i podorozhnik: kreativnoye agentstvo «Moloko» provelo dizayn-issledovaniye logotipov belaruskikh i zarubezhnykh medtsentrov [Lots of blue, heart and plantain: creative agency "Moloko" conducted a design study of the logos of Belarusian and foreign medical centers]. - 23.09.2019. - URL : https://marketing.by/analitika/mnogo-sinego-serdtse-i-podorozhnik-kreativnoe-agentstvomoloko-provelo-dizayn-issledovanie-logotipov/ (Accesses: 28.02.2021).

9. Dizayn-issledovaniye logotipov restoranov i konditerskikh Belarusi, Rossii i dalnego zarubezhia [Design research logos of restaurants and confectionery in Belarus, Russia and far abroad]. - 30.03.2020. - URL : https://mlk.by/dizajn-issledovanie-logotipov-restoranov-ikonditerskih-belarusi-rossii-i-dalnego-zarubezhya/ (Accesses: 28.02.2021).

10. Lefrere J.J. Transfusion, blood donation, and postage stamps: a worldwide review / J.J. Lefrere, B. Danic // Transfusion. - 2010. 50. - P. $1838-1848$.

11. Lefrere J.J. Blood donation on posters: a worldwide review / J.J. Lefrere, B. Danic // Transfusion. - 2012. - 6(52). - e1-e14.

12. Khomenko L. Analysis of the Marketing Activities in the Blood Service: Bibliometric Analysis / L. Khomenko, L. Saher, J. Polcyn // Health Economics and Management Review. - 2020. - 1. - P. 20-36.

13. Khomenko L. Analiz reklamy sluzhby krovi v drukovanykh ZMI (na prykladi Sumskoho oblasnoho tsentru sluzhby krovi) [Analysis of blood supply service advertisements in print media (on the example of Sumy regional blood supply service center)] / L. Khomenko, L. Saher, V. Liubchak // Halytskyi ekonomichnyi visnyk [Galician economik journal]. 2020. - 5(66). - P. 170-179.

14. Liubchak V.V. Istoriia sluzhby krovi [History of blood service] : monograph / V.V. Liubchak, A.S. Tymchenko, V.P. Liubchak, L.M. Khomenko. Sumy : Sumy State University, 2020. - 336 p.

15. Khomenko L.M. Pinterest yak suchasnyi marketynhovyi instrument $\mathrm{v}$ tsyfrovii ekonomitsi [Pinterest as a modern marketing tool in the digital economy] / L. M. Khomenko // III Vseukrainska naukovo-praktychna internet-konferentsiia "Marketynh v umovakh rozvytku tsyfrovykh tekhnolohii" [III All-Ukrainian scientific-practical Internet conference "Marketing in the conditions of digital technologies development"] : conference paper. - Lutsk : IVV Lutsk NTU, 2020. - P. 208-211. 